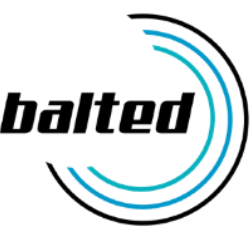

Balkanlarda Türk Dili ve Edebiyatı Araştırmaları

Studies on Turkish Language and Literature in the Balkans

Seyfula, S. (2021). 'Gülün Adı' Romanının Türkiye ve Kuzey Makedonya Baskılarında Paratekst Unsurların Postmodernizm Bağlamında Mukayesesi. Balkanlarda Türk Dili ve Edebiyatı Araştırmaları, 3(2), 301-313. DOI: 10.47139/balted.971781

\title{
'Gülün Adı' Romanının Türkiye ve Kuzey Makedonya Baskılarında Paratekst Unsurların Postmodernizm Bağlamında Mukayesesi
}

\author{
Comparison of the Editions in Turkey and in North Macedonia of the Novel \\ 'The Name of the Rose' Within the Context of Paratext
}

\section{Sezen SEYFULA*}

\begin{abstract}
Öz
Bu çalışmada İtalyan yazar Umberto Eco'nun en çok satan romanı 'Gülün Adı' romanının Türkiye ve Kuzey Makedonya baskılarındaki Postmodern anlatı biçimi olan 'Paratekst' (yan metin-metin dışı) unsurların karşılaştırılması yapılmıştır. Postmodernizm ve postmodern romanın özellikleri hakkında genel bilgi verildikten sonra Paratekst kavramı tanıtılmış ve örneklem romanımızın iki ülke yayınları arasındaki benzerlik ve farklılıklara dikkat çekilmiştir. Postmodernizm Türkiye ve Kuzey Makedonya'da olduğu gibi Balkanların bütünü için de çok yeni bir edebî akımdır. Bu bağlamda Paratekst kavramı da edebiyat yorumunda henüz yenidir ve yeterli bir literatüre sahip değildir. Bu çalışmada romanın Can ve Tabernakul yayınevleri baskısı olan iki farklı tercümesinin paratekst açısından benzerlik ve farklııkları ele alınmıştır.
\end{abstract}

Anahtar Kelimeler: Türkiye'de yayıncılık, Kuzey Makedonya'da yayıncılık, çeviri, postmodernizm, paratekst, Umberto Eco, Gülün Adı.

\begin{abstract}
In this study it has been analysed the differences and the similarities in aspect of Paratext between the Turkish version published in Turkey and Macedonian version published in Macedonia of the bestseller novel 'The Name of the Rose' by the Italian author Umberto Eco. This study is starting with the details about Postmodernism, the characteristics of the postmodern novel and the short history about the Paratext. Postmodernism actually is a new literary movement not only for Turkey and North Macedonia but also for the whole Balkans. Especially there is no enough information about the postmodern narrative form the 'Paratext'. We analyzed the differences and the similarities in aspect of Paratext between the Turkish and Macedonian versions published by Can and Tabernakul publications.
\end{abstract}

Keywords: Publication in Turkey, publication in North Macedonia, translated publications, paratext, Umberto Eco, The Name of the Rose.

\footnotetext{
* Dr. Öğr. Üyesi, Entegre İşletme Üniversitesi, Ticaret ve Ekonomi Fakültesi, Üsküp/KUZEY MAKEDONYA, sezenseyfullah@gmail.com, ORCID: 0000-0003-3269-6690
} 


\section{Giriş: 1. Postmodernizm Hakkında Genel Değerlendirme}

"Post", İngilizcede Modernizm'den sonra gelen anlamında kelimeye eklenen bir ön ektir. Esasen Postmodernizm de Modernizm'den sonra gelen döneme işaret eder ve bir diğer ifadeyle yeni edebi akımın adıdır. Brian McHale 'Postmodern Fiction' (Postmodern Kurgu) adlı çalışmasında Postmodernizm'deki (Ingilizcede "ism", Türkçede "izm") son ekin iki işlevi olduğunu iletir. Bunun kronolojik bir sınırlandırma olmadığını, sadece sistematik ve düzenli bir ayrışma olduğunu bildirir. Ona göre, Postmodernizm ya da Postmodern olan, Modernizm'den doğan değildir, ardından gelendir (McHale, 1977, s. 5).

Gencay Şaylan ise 'Postmodernizm' adlı eserinde (2002) bize Arnold Toynbee'nin eserinde geçen bir sıralamayı iletmektedir. Arnold Toynbee'ye göre, Batı dünyasında, dört dönemden bahsedilir: Karanlık Çağ (7. ve 11. yüzyıl arası), Orta Çă̆ (11. ve 15. yüzyıl arası), Modern Çağ (15. ve 19. yüzyıl arası) ve Postmodern Çağ (19. yüzyıldan bu yana). Toynbee'ye göre; Postmodern dönemin en önemli özellikleri savaşlar, devrimler ve kargaşadır. (Şaylan, 2002, s. 17).

Bugün, her ne kadar bilim dünyasında Postmodernizm'in ne zaman başladığı konusunda bir fikir birlikteliği olmasa bile, farklı bilim adamı ve araştırmacıların bu konuda ileri sürdükleri belli başlı fikirleri belirtmekte fayda vardır:

1. Postmodernizm algısı ilk olarak Alman yazar Rudolf Pannwitz'in 'Die Krisis der europaeischen' (Avrupa'nın Krizleri) adlı eserinde bahsedilir. Bu ifadeyi de müellif Batı kültürlerinde Birinci dünya savaşının yıkıcı özelliğini vurgulamak için kullanmaktadır. (Pannwitz, 1917)

2. Postmodernizm terimini ilk kullanan 1934 yılında basılan "Antologia de la Poesia Espanole e Hispanoamericana" (Ispanyol ve Latin Amerika Şiiri Antolojisi) adlı modernizm karşıtı bir tavrı anlatan kitabıyla Federico de Onis'dir. (Yamaner, 2007, s. 14)

3. XVII. yüzyılda bir aydınlanma fırtınası ile esmeye başlayan ve iki asır boyunca bütün hayatı, kültürü kuşatan modernitenin ardından, Postmodernizm Batı'da XX. yüzyılın hemen hemen ilk çeyreğinde kendini hissettirmeye başlamıştır. 1980'ler, Türk romanında çok keskin ve önemli bir dönemecin başlangıcıdır. Zira bu döneme kadar Tanzimat'la birlikte baş köşeye kurulan katı Realizm, postmodern söylemin estetik darbesiyle tahtından edilir. Yaklaşık 150 yıl süren rasyonalist mantığın yerini, bu yeni yaklaşıma bırakma süreci dikkate değerdir. (Koçakoğlu, 2011, s. 187)

4. "Postmodern, Postmodernlik, Postmodernite, Postmodernizm kavramları ilk defa 1930'lardan itibaren duyulmaya başlanmış, 1950'li yıllarda Anglo-Amerikan edebiyat eleştirisine girmiş, ardından mimaride kullanılmış, 1960'lı yıllardan itibaren de yaygınlaşmıştır. Postmodernizm, önceleri İkinci Dünya Savaşı sonrası 
dönemi ve eleştirisini tanımlamak için kullanılmış, daha sonra felsefi anlamlar kazanarak felsefi bir tanımlamanın ifadesi olmuş, ardından da politika, tarih ve ekonomi alanlarına yayılmış; hatta tüm hayatı kapsayan bir bakış tarzı, mimaride bir yöntem, edebiyat ve diğer sanat dallarında bir akımı ifade eden kavram haline dönüşmüştür." (Çetişli, 2015, s. 163).

5. “ilk defa Arnold Toynbee tarafından 1939'da yayımlanan bir eserinde kullanıldığı sanılan Postmodernizm terimi, biraz da konunun gerçek anlamda tartışılma eksikliğinden dolayı, bir yandan son derece karmaşık ve zor felsefi anlamlar ile dile getirilirken diğer yandan çağdaş kültürde yer alan nihilist ve sinik bir eğilimi oluşturan son derece basit ifadelerle tanımlanmaktadır. Ayrıca postmodernizmi doğası gereği tanımlamak da pek doğal sayılmamaktadır." (AslanAbdullah; 2001, s. 98)

6. Postmodernizm, 1960 '। yıllarda Fransa'da ortaya çıkan 1970'li yıllardan itibaren de $A B D$ 'de yaygınlaşan bir düşünce akımı olarak takdim edilmektedir. (Doltaş, 1999, s. 23).

Yukarıda adı geçen araştırmalardan yola çıkarak Postmodernizm'in genel çizgileriyle belirtilebilecek bir başlangıcı olsa da, Postmodernizm döneminin resmî bir duyurusu, resmî bir başlangıç tarihi bulunmamaktadır. Böyle bir manifestosu olmayan bir edebiyat akımının tarihçesinden bahsetmek biraz zordur. Ancak öyle ya da böyle bir tarihî gelişiminden bahsedilmesi mümkündür. Aşağı yukarı Birinci Dünya Savaşı zamanlarında ortaya çıktığına inanılıyor. Söz konusu akım Edebiyat dünyasında en büyük gelişimini İkinci Dünya Savaşı sırasında yaşamışırır. Batıda gelişen bu akım, sonrasında Doğu'daki Oryantalist edebiyatlara da etki etmiştir. Özellikle 1980'lerden itibaren Türk Modern Edebiyatı da bundan nasibini alarak Postmodern Türk Edebiyatı'na kapı aralanmıştır. Geçen yüzyılın sonlarına doğru Batı edebiyat akımlarının Türk romanında etkileri sürmektedir ancak spesifik olarak Postmodern roman türü Türk Edebiyatı'na 1980'lerde girmiştir. 1990'larda ise bu edebiyatın eleştirileri baş göstermiştir.

İkinci Dünya Savaşı'ndan sonra Alain Robbe Grillet ve arkadaşları, önceki edebi akımları eleştirerek yeni bir roman akımını geliştirmişlerdir. Bu akımın, Postmodern romanın nüvesini teşkil ettiği belirtilmektedir (Yaprak-Bayrak, 2017, s. 148).

Postmodernizm bir dönemin sona ermesiyle başlayan yeni bir dönem değildir. Postmodernizm aynı sürecin zorunlu bir şekilde farklılaşmasıyla ortaya çıkmıştır. Bir başka ifadeyle, düşünen bir varlık olan insanın kendi tercihlerini yapmaya başladığı dönemdir. Modernizm daha çok eski geleneklere bağlı bir şekilde sahneye çıkan bir akımdı. Ancak Postmodernizmin de tam anlamıyla yepyeni ya da tamamıyla farklı bir yaşam stili olduğunu söylemek mümkün değildir.

Modernizm ‘Pragmatizm'e önem verir, ancak Postmodernizm için gerçeklik tek 
taraflı bir doğru değildir. Felsefe şekli olarak Pragmatizm'in merkezinde gerçeklik yer alır ve bu yüzden Modernizm akımına etki etmiştir. Bu moktada demokrasi ve çifte standartlar, hızlı gelişen teknoloji, sanayileşme, tek tip hayat çeşidi, kapitalizmin kölesi olmak gibi durumlar Postmodernizm'in ortaya çıkmasına sebep olmuştur.

Edebi eleştiri alanında Postmodernizm'in özellikle Postyapısalcılık, Postsanayileşme gibi terimlerle olan yakınlığından bahsedilerek, bu kavramlara odaklanılmıştır (Şaylan, 2002, s.41).

Kimlik arayışına giren insanlar, Modernizm sürecini durdurma ihtiyacı duymuşlardır. Sebep olarak da Modernizm içinde kimliğin kaybolduğu gerçeği ileri sürülmüştür. Postmodern sanatçılar daha özgürce ve daha rahat davranmayı istemişlerdir. Bu süreç başladığında artık kendi aklıyla kendi kararlarını alan sanatçı bir birey olarak ortaya çıkmıştır. Bir tarafta gelenekleri reddeden Modernistler, diğer yandan da kendi kararlarını kendileri veren Postmodernistler. Postmodernizm ile, genel ve evrensel tabuları yıkmaya kararlı bir sanatçı ruhu ortaya çıkmıştır. Ruh ve kalp, bir konu hakkında istediğini yazan bir Postmodernist'tir. Modernistler, evrensel insanı anlatırken, Postmodernist ise kararlarını kendileri alır, arşiv ve hafızalardaki karakteri yazmak için kendi tercih hakkını kullanır olmuştur. Bu itibarla Postmodern yazarlar, sürekli değişiklik gösterir, yeniden şekillendirir ve istediklerini kullanırlar.

Hayat kurallarından kurtulan Postmodern yazar, ironi içeren eserler vermeye başlar. Modernistler tarafından kabul edilen Pozitivizm tamamıyla terk edilir. Çünkü Pozitivizm teolojik ve metafizik düşünce sistemlerini yararsız kabul eden bir felsefedir. Pozitivizm, deneysel bir felsefedir, Matematik ve Fizik bilimleri sayesinde objektif dünyanın bilimsel doğruluğunu kanıtlamaya çalışır. Oysa Postmodern yazar gerçeğe kendi önsezileriyle varmaya çalışır. Postmodern yazarlar 'Gerçek nedir?, Doğru nedir?, Gerçeğin tek bir açıklaması olabilir mi ki?!' gibi sorular sormaktadır. Gerçek, Postmodernistlere göre hep değişken olmuştur. Onları ilgilendiren şey gerçekten daha çok tarihin karanlık noktalarıdır.

\section{Postmodern Romanın Özellikleri}

Geçmişten günümüze klasik ve modern romanlarda teklik ve merkezîlik öne çıkan husus olmuştur. Teklik ve merkezîlik romana bir bütünlük vermektedir. Postmodern roman ise bu özelliklere başkaldırarak ortaya çıkarak teklik ve merkezîliğe karşı çıkar. Postmodern roman için gerçek göreceli bir kavramdır ve bütünlük aramanın bir değeri yoktur. Romanın örgüsü tek bir kişinin etrafında gelişmez. Halihazırda bahsettiğimiz gibi klasik romanlarda kişiler ve olaylar ana kahramana bağlanır. O dönemde yazarlar bu tür romanlar kaleme aldıkları gibi, tek seçeneğin bu olduğu düşüncesindeydiler. Bunu bir şartlanma olarak da kabul etmek mümkündür. O dönemdeki yazarlar bu sınırlar dışına çıkmayı sevmedikleri 
için evrensel olay ve kişiler genel tercihleri olmuştur. Postmodern romanlarda ise tek olay ve tek kahraman romanı süslemez, süsleyemez. Standartların dışına çıkmak istemeyen modernist ve klasikçilerin bu tercihi ise Postmodernistler tarafından bir eksiklik ve değersizlik olarak görülür. Standartları aşan bir roman yazma şekline sahip olan Postmodernistler özgürlüğün tadına varan, tercihlerini kendi kendilerine yapan bir yazı sürecine girmişlerdir. Artık tek kahraman ve tek olaya endeksli olmayan yazarlardan ötürü romanda yeni bir anlayış ortaya çıkmaya başlamıştır. Postmodernizm sayesinde monotonluktan uzak bir roman türü ortaya çıkmış; metinlerarasılık kullanılarak oyun içinde oyundan bahsedilen bir roman söz konusu olmuştur. Modern roman bütünlüğün 'şaheser'i sayılırken, Postmodern roman ise özgürlüğün ve an'dan uzaklaşmanın romanı olarak bilinmiştir.

Son günlerde herhangi bir okur postmodern roman okuyunca 'her şeyin dağınık olduğunu', 'romanı anlamakta güçlük çektiğini' iddia eder. Bugün hayatımızda önemli bir yer alan Postmodern romanlar "günlük" romanlar olmayıp, yazarın keyfi seçimine göre değişimlerin oluşması sonucunda özgürlüğün yansıması ya da edebi açıdan önem taşıyan tarihe yolculuk yapıp içinde bulunulan andan uzaklaşmaktır.

"Roman Allah'ı olmayan bir dünyanın destanıdır, kişilerin ruh hali şeytanları hatırlatmaktadır." (Lukács, 1971, s. 558). Postmodernizm'de metinle dünya arasındaki bağlantı, gerçek olana bir geri dönüş lehine metnin silinmesi yoluyla değil, metinselliğin gerçek olanla örtüşmesini sağlayacak şekilde yoğunlaştırılması yoluyla yeniden kalıba dökülmüştür (Connor, 2001, s. 179). Postmodern romanlarda dilin doğallığı bir sorun olarak gündeme getirilir. Hiçbir anlam, bütüncül nitelik taşımaz. Bu durumda, tam olarak bir gerçekliğe ulaşılamayacağı düşüncesinden yola çıktığımızda her şey gerçek değil, 'gerçekmiş gibi' algılanır yani yorumlanır (Yalçın-Çelik, 2005, s. 42-43). Bu yazarlara göre romanla gerçek arasındaki ilişki 'hayaldir', romanın yaşama benzemesi söz konusu olamaz, çünkü roman bir yaratı; insan zihninin bir ürünüdür. Bu yaratının malzemesi ise dil'dir (Menteşe, 1996, s. 100). Grillet'nin kişiyi değil kişinin gördüğü nesneyi öne çıkaran, anlamı hazır bir şekilde okura sunmayan, içeriği değil biçimi önceleyen, olayı geri plana alan roman anlayışı ise zaman içinde başka kuramcıların da ilavesiyle günümüzde postmodern roman ya da postmodern anlatı denen türü meydana getiren ve kavramsal altyapısını zenginleştiren unsurlar olarak ortaya çıkarmıştır. Ancak postmodern, modernle ilgili hemen her şeyi sorguladığı için, bu yeni türün ne kadar "roman" olduğu da tartışılmıştır. Bu nedenle "postmodern bir metnin tahlilinde belki de en güçlük çekilen nokta, metnin türselliği konusunda yaşanan şüphelerdir.' (Yaprak-Bayrak, 2017, s. 149).

Oya Batum Menteşe, "Sanatta ve Edebiyatta Postmodernizm" başlıklı yazısında okuduğu postmodern bir roman hakkında şöyle bir yorum yapmıştır "Bir roman okuyorum! Amerikalı yazar, Richard Brautigan'ın Amerika'da Alabalık Avı adlı 
romanını. Ancak, bir türlü ne okuduğumu anlayamıyorum. Toparlayamıyorum. Her şeyden önce eserde bütünlük yok; bölümler arası bağlantılar kopuk; olaylar mantıksal bir düzen içerisinde gelişmiyor; kişilerin birbiri ile ilgisi yok, hatta doğru dürüst bir roman kişisi bile yok denebilir." (Menteşe, 1995, s. 273-283) Bu görüşle doğru orantılı olarak postmodern metinlerde modern metinlerindekilerin tersine irrasyonel, birbirinden kopuk, karmaşık ve neredeyse olmayan bir olay örgüsü ile karşı karşıya olduğumuzu gerçeği ortadadır ve bu algı ile söz konusu eserlere yaklaşma zorunluluğu okuru beklemektedir (Güvenç, 2007, s. 204).

\section{Paratekst (Yan Metin - Metindışı Unsur)}

Bir romanı postmodern yapan en önemli iki unsur, iki anlatı biçimi: 'Üstkurgu' ve 'Metinlerarasılık' anlatı biçimleridir. Henüz Türk Postmodern Edebiyatı'nda "Paratekst" yani metin dışı unsurlar gerektiği kadar ele alınmamış olsa da Batı dünyası eleştirmen ve kuramcıları Postmodern romanın unsurları arasında 'Paratekst'i de göstermektedirler. Söz gelimi Gerard Genet eserlerinde bu yeni ve yeterince bilinmeyen Postmodern unsurlardan sıklıkla bahseden araştırmacılar arasındadır (Genette, 1987). Thomas Dadessio'nun ise Umberto Eco'nun ilk romanı olan 'Gülün Adı' romanını bu açıdan incelediğini belirtmekte yarar vardır (Daddesio, 1988).

Hiper bağlantılar belirmeden çok daha önce, kimi zaman basımdan da çok önceleri, insanlar bir metin içinde başka bir metinden nasıl bahsediyorlardı? Tarihi nasıl o anın metnine hikâye ediyorlardı? Onların yaptıkları tam anlamıyla kitabı bir yerinden yırtıp aralarına yeni bölümler koymaktı. Ya da önsöz/öndeyiş ve sonsöz/sondeyişler eklemekti. Bazen de ana metinden önce ya da sonra resimler kullanılmaktaydı. Kitabın orijinalinden bahsedilmiyorsa da romanı tercüme edenlerin önsözleri de eklenirdi. Bu gibi yan metin ya da metin dışı unsurlara edebiyat dilinde 'Paratekst' denilmektedir. Bu konuda en kapsamlı teorik bilgileri veren önemli araştırmacılardan Anne Hedeman 2019 yılında "Inscribing Knowledge in the Medieval Book: The Power of Paratexts" ismiyle yayımladığı çalışmasında bu konuya odaklanır. 'Paratekst'in Gücü' adını taşıyan bu kitapta Hedeman, Orta Çağ'dan kalan eserlerdeki paratekstlerde su yüzüne çıkan siyasi güce dikkati çekmektedir. Hedeman, kitabın bir bölümünde paratekstlerden bahsederken; 'Fransız Tarihi Metinlerdeki Önsöz ve Önsöz Resimlerin Tercümesi' tarzındaki başlığı kullanır ve özellikle tercümelere dikkati çeker. Bir diğer ifadeyle metinlerarasılık hakkında bir nevi ipucu veren yan metinlere. Birçok kitabın paratekstlerini inceleyen yazar bu örnekleri seçerken, en göze batan nokta renkli, alacalı resimler, tezhipler, metinde açıklanan sahneleri ele alır. Bu örneklerde görsel resimlerde ilaveler ve çıkarmalar olabilir. Bütün bunlar paratekstin görsel materyallerdir. Yazar, romanlarda fotoğraflar olmasa onların popüler olamayacağını söylemektedir. Elle kopya edilen kitap okuyucularının o dönemde 
asil olduklarını dile getiren yazar, aynı zamanda bu kitapların kendisi gibi tarihçiler tarafından ilgi çekeceğini bildiğinden bu kitapların o dönemde bu yüzden elle kopya edildiklerini söylemektedir. Bunun, tarihin şekillenmesinde yardımcı olacağını düşünür.

"Paratekst" ilk olarak Fransız edebiyat eleştirmeni Gérard Genette tarafından ortaya atılan bir terimdir. Genette "Paratekst" için özetle şunları söyler: 'Paratekst bir metnin kitap olmasını sağlayan, onu okuyuculara daha doğrusu kamuya önerilmesini sağlayandır.' (Genette, 1987, s. 1). Genette, paratekst yani metin dışı unsurların metni kitaba dönüştürdüğünü dile getirmektedir. Paratekst, bir metin ile diğer metin arasında bir aracıdır, eserin bütünlüğünü sağlar.

\section{4. 'Gülün Adı' Romanında Paratekst Unsurlar (Türkiye ve Kuzey Makedonya Baskıları Özelinde)}

\subsection{Türkiye Yayını (Can Yayınları)}

Gülün Adı romanı Umberto Eco'nun en bilinen, en fazla dile tercüme edilen romanlarından biridir. Okuyucu kitlesinin genel profilini ortaya koyan sosyal medya kitap paylaşımları sayfalarından takip ettiğimiz kadarıyla da okuyucu dünyası bu ve buna benzer romanları okumakta güçlük çekmektedir. Özellikle sıradan okurların, edebî eleştirel bir gözle bakmadıklarında bu tür postmodern romanları yarıda bıraktıklarına şahit olunur. Oysaki Postmodern romanlar gibi, ana karakter ve olayların çok olduğu romanlarda bütün bilmece son cümle okunduğunda çözülmektedir. 'Paratekst' gibi metin dışı unsurlar da bu içeriğin anlaşıımasında ekstra bilgiler vermekte ve okura yardımcı olmaktadır. 7 günde 7 cinayetin işlendiği bu romanda baş kahramanlar anlatıcı Adso ve Başkomiser William gibi görünse de aslında eserin kurgusu Melk Manastırı'nda yaşayan keşişlerin hikâyesinden ibarettir. Son cümle okunduğunda romandaki 'puzzle' tamamlanmış olur. Bu roman eğer Postmodern bir roman olmasaydı büyük ihtimalle 'Manastır'da 7 Günde 7 Cinayet' ismini taşıyabilir ve eser derinlemesine okunmadan ana kurgusu önemli oranda çözülmüş olurdu.

Öncelikle bir kitabın en önemli paratekstinin kapağı olduğunu söyleyebiliriz. İtalyanca baskılardaki kapak yayınlarına bakıldığında, birçok versiyon olduğu görülmektedir. Kiminde Melk Manastırı resmedilmiş, kiminde William ve Adso bir labirentin içinde resmedilmiştir. Bazı kitap örneklerinde ise sadece farklı renk kombinasyonları ile kitabın ismi ve yazarı yer almıştır. Romanın Türkiye'de en çok okunan tercümelerinden biri de Can Yayınları tarafından yayımlanmıştır. Kitabın orijinali 1980 yılında İtalya'da yayımlanırken, Türkiye'de ilk basımı 1 Ocak 1986 yılında Can Yayınları tarafından yapıımıştır. Tercümesini Şadan Karadeniz yapmıştır. İlk baskısındaki kapağında sağda en üstte "Umberto" yazarken "Eco" soyadı kitabın kapağını kaplayacak şekilde aşağıdan yukarıya sırasıyla sağ ve sol taraflara dağılmıştır. Kapak fotoğrafının ortasında içi boş olan ve sadece siyah çizgilerle 
resmedilmiş şeffaf bir haç çizilmiştir. Tam ortasında kırmızı bir gülün kuşbakışı resmi bulunmaktadır. Romanın ismi sağ üst köşede aşağıdan yukarıya iki sıra şeklinde dikey yazılmıştır. Aşağıda solda çevirenin ismi yazmaktadır yani "Şadan Karadeniz". Sağda da baskı numarası ve basımevinin ismi "Can Yayınları" yazmaktadır. Günümüzdeki baskılarında ise kubbeli girişi olan beyaz bir yapının içinden çekilmiş bir fotoğraf bulunmaktadır. "Umberto Eco" ismi en yukarıda; beyaz kapağın üstünde yer alır. Altında siyah harflerle romanın ismi yazılmıştır. Resmin sağında üst tarafta yukarıdan aşağıya roman yazmaktadır. Resmin aşağııında "Çeviri: Şadan Karadeniz" yazmakta, onun altında da Can Yayınları'nın logosu olan "CAN" ve üstünde kalp simgesi bulunmaktadır.

Çalışmamızda incelenen yayın, romanın 37. baskısı olarak 2016 yılında İstanbul'da Can Yayınları tarafından 3000 adet basılmıştır (Eco, 2016). Yayın doğrudan İtalyancadan tercüme edilmiştir. Yayında öncelikle "iç̧indekiler" bölümü yer alır. Ardından sıradaki sayfada 'Açıklama' başlıklı Can Yayınlarına ait bir paragrafık yazı bulunmaktadır. Sıradaki sayfada Manastır'ın bölümleri bir harfle işaretlenerek yazıımıştır, Manastır'ın planı üzerinde de bu harfler yerleştirilmiştir. Postmodern romanlarda olay bir mekânda geçerken böyle planların gösterilmesi daha doğrusu metin dışı fotoğrafların yerleştirilmesi doğal bir özelliktir ve örneklem romanımızda da tatbik edilmiştir. Bölüm adlandırmaları sırasıyla şöyledir: A Aedificium, B - Ağıllar, C-Ahırlar, D - Avlu, E-Demirhane, F-Hamam, G - Kilise, H - Revir, I - Toplantı Salonu ve J - Yatakhane.

'Gülün Adı Üzerine' başlığı altında 'Umberto Eco ve Gülün Adı' alt başlık yazısı bulunmaktadır (Eco, 2016, s. 15). Adı geçen başlık ve sıradaki alt başıklar 'Romanın Adı' (Eco, 2016, s. 17), 'Çeviriye Değin' (Eco, 2016, s. 18) alt başlıkları kitabın tercümanı Şadan Karadeniz'e aittir. Romanın postmodern olduğunu gösteren, metinlerarasılığın en bariz göstergelerinden biri olan bölüm 'Doğal Olarak Bir Elyazması' adlı ana metin dışı paratekst bölümdür (Eco, 2016, s. 24). Bu bölümdeki İtalyanca kısımlar doğrudan Türkçeye tercüme edilirken, Latince kısımlar olduğu gibi bırakılmıştır. İnandırıcılık katmak için "Umberto Eco 5 Ocak 1980" tarihi düşülmüştür. Bu paratekstin ilk paragrafı önemli bilgileri de ele vermektedir:

"16 Ağustos 1968'de Vallet diye bir rahip tarafından kaleme alınmış bir kitap geçti elime: Melk'li, Dom Adso'nun, Dom J. Mabillon'un baskısından Fransızcaya çevrilmiş elyazması (Presses de L'Abbaye de la Source, Paris, 1842). Gerçekten oldukça yoksul tarihsel bilgilerin eklendiği bu kitabın, Benedikten tarikatının tarihine ilişkin çok şey borçlu olduğumuz, on altıncı yüzyılda yaşamış büyük bilgin tarafından bulunmuş olan, on dördüncü yüzyıla ait bir elyazmasının tıpkısı olduğu öne sürülüyordu. Bu bulgu (kronolojik sıraya göre üçüncü olan kendi buluşumdan söz ediyorum), sevdiğim birisini beklemek üzere Prag'da bulunduğum sırada beni neşelendirdi. Altı gün sonra Sovyet birlikleri talihsiz kenti istila ettiler." (Eco, 2016, s. 24). 
Ayrıca NOT bölümünde (Eco, 2016, s. 30) Adso'nun 7 gün içerisinde uygulanan dua saatlerinin İtalyanca ve Türkçe listesi verilmektedir. Söz konusu liste şu şekilde sıralanmaktadır:

Mattutino (Geceyarısı) (bazen Adso buna eski deyimle Vigiliae de demektedir.) Gecenin 2.30'uyla 3'ü arası.

Laudi (Alacakaranlık) (daha eski gelenekte Matutini denirdi.) Sabahın 5'iyle 6'sı arası: tanyeri ağarırken sona erer.

Prima (Tansökümü) 7.30’a doğru, gündoğuşundan az önce.

Terza (Sabah) 9'a doğru.

Sesta (Öğle) Öğle rahiplerin tarlada çalışmadıkları bir manastırda, kışın, aynı zamanda öğle yemeği vakti).

Nona (ikindi) Öğleden sonra saat 14.00 ile 15 arası.

Vespro (Günbatımı) 16.30'a doğru, günbatımı (Kural, karanlık basmadan akşam yemeği yenmesini öngörür).

Compieta (Akşam) 18.00 dolayları (rahipler saat 19'dan önce yatarlar).

Saatlerin hesaplanması, Kuzey İtalya'da, Kasım sonunda, güneşin yaklaşık 7.30 'da doğup öğleden sonra 16.40 'ta batması esasına dayanmaktadır. (Eco, 2016, s.31)

Eserde ayrıca 'Son Yaprak' isimli Umberto Eco'ya ait bir Epilog bölümü yer almaktadır (Eco, 2016, s. 677). Ana metnin sonunda 'Gülün Adı Üstüne Umberto Eco'nun Açıklaması' isimli metin başlığı bulunmaktadır. (Eco, 2016, s. 687) Huana Ines De La Cruz'a ait İspanyolca bir şiirin yer aldığı 'Sonrası' (İtalyanca aslı: Postille) başııklı yazııının Türkçe tercümesi de yer verilen unsurlar arasındadır. Bu bölüm de şu alt başlıklar bulunmaktadır:

1. Kitabın adı ve anlamı (Eco, 2016, s. 691)

2. Süreci anlatmak (Eco, 2016, s. 695)

3. Kuşkusuz, ortaçağ (Eco, 2016, s. 697)

4. Maske (Eco, 2016, s. 700)

5. Kozmolojik bir olgu olarak roman (Eco, 2016, s. 701)

6. Konuşan kim? (Eco, 2016, s. 706)

7. Suskuyla geçiştirmek (Eco, 2016, s. 710)

8. Soluk (Eco, 2016, s. 711) 
9. Okuyucuyu oluşturmak (Eco, 2016, s. 714)

10. Polisiye metafizik (Eco, 2016, s. 718)

11. Eğlence (Eco, 2016, s. 720)

12. Modern sonrası, ironi, hoşa giden (Eco, 2016, s. 724)

13. Tarihsel roman (Eco, 2016, s. 729)

'Bitirirken' isimli son bölüm (Eco, 2016, s. 732) şu notla başlamaktadır: "Romanı yazdıktan iki yıl sonra, üniversiteye gittiğim 1953 yılından kalma bir not geçti elime."

\subsection{Kuzey Makedonya Yayını (Tabernakul Yayınları)}

Çalışmamızda odaklanılan romanın Makedonca Kiril alfabeli tercümesinde Tabernakul Yayınlarından çıkan baskısı esas alınmıştır. Kitabın ön kapak fotoğrafıyla arka kapak fotoğrafı bir bütünü oluşturmaktadır. Üst üste koyulmuş iki adet koyu renkli kitabın etrafı karanlıktır. Ön kapakta tam ortada romanın ismi Windows yazı tiplerinden 'Old English Text MT' fontuyla yazılmıştır. Ön kapakta en üstte ortada yazarın ismi dururken, en altta ortada ise yayınevinin ismi yer almaktadır. Ön kapağın içeriye doğru kıvrılmış uzantısında Umberto Eco'ya ait bir yazı bulunmakta ve ön kapağın bir parçasını teşkil etmektedir. Kitabın birinci baskısı 2006 yılında yapılmıştır. Kapaktan sonraki sayfada kitap bilgileri yer almaktadır. Bu bilgiler arasında İtalyanca orijinalinin basıldığı yer, yayın evi ve tarihi, altında da Makedonca baskısının tarih ve yayın evi yer alır. Bir sonraki sayfada yazarın ismi, altında yine Microsoft Word sayfasındaki yazı çeşitlerinden 'Old English Text MT' fontuyla yazılmış roman başlığı, onun altında da İtalyanca'dan romanı tercüme eden çevirmenin ismi verilmiştir. Romanı Makedoncaya Mariya Gratsiya Tsvetkovska tercüme etmiştir. Onun altında da yayınevinin logosu, ismi ve kitabın basım yılı (2006) yer almaktadır. Sonrasında yan metin olan 'Doğal Olarak EI Yazması' (Се Разбира, Ракопис) başlıklı metin gelmektedir. Bir sonraki sayfada Not (Белешка) (Еко, 2006, s. 13) isimli yan metin/paratekst yer almaktadır. Adson'un el yazmasının 7 bölüme ayrıldığını belirten bu yazı Türkçe versiyonunda da farklı bir sıralandırmayla yer almıştır. Ardından dua bölümlerinin Makedoncaları verilmiştir. Onlar da Türkçesinde yer alan aynı sırayla şu isimleri taşımaktadır: Утрена (Utrena), Хвалитни (Hvalitni), Прв Час (Prv Ças), Трет Час (Tret Ças), Шести Час (Şesti Ças), Деветти Час (Devetti Ças), Вечерна (Veçerna), Повечерие (Poveçerie) (Еко, 2006, s. 13-14). Ardından Türkçe versiyondaki gibi Manastırın kuşbakışı planı daha büyük bir şekilde verilmektedir (Eко, 2006, s. 15). Sonrasında 'Prologo' bölümü yani Öndeyiş bölümü Пролог (Okunuşu: Prolog) adıyla bir bölüm verilmiştir (Еко, 2006, s. 16). Bu metinden sonra ana metne, yani 'Birinci Gün' alt başlıklı birinci bölüme geçilmektedir. Son Yaprak (Еко, 2006, s. 748) ve İçindekiler (Еко, 2006, s. 757) Türkçe versiyonunda olduğu gibi ana metinden sonra verilmektedir. Buradaki tek 
eksik 'Sonrası' isimli dergi yazısıdır. En son sayfada kitabın yayınıyla ilgili yayınevi bilgileri yer almaktadır. (adres, web sitesi, yayın evi müdürü, genel yayın yönetmeni, editör, tercüman, redaksiyon isimlerinin, ISBN numarasının yer aldığı bilgiler) Arka kapağın içe doğru uzantısı olan bölümde de Umberto Eco'nun hayatı ve edebi kişiliği, yayınları hakkında bilgi verilmektedir. Arka kapak ön kapaktaki resmin uzantısı olduğu için arkada yayınevinin logosu ve kitabın ISBN numarası dışında bir bilgiye rastlanmamaktadır.

\section{Sonuç}

Farklı ülkelerde yayımlanan her iki tercüme hakkındaki tespitlerimiz neticesinde eserin orijinalinde de yer alan ve Postmodernizmin ana unsurları metinlerarasılık ile üstkurgunun bu eserdeki yansıması olan 'Doğal Olarak Bir El Yazması' bölümünün esas tercümesine her iki yayında sadık kalınarak verildiği görülmektedir. Aynı zamanda Postmodern romanlarda olay yeriyle alakalı fotoğraflar, şemalar göstermek ortak bir unsur olduğu için, bu konuda da her iki yayın orijinale bağlı kalmıştır. İbadet saatlerinin açıklamalı noktalarının her iki yayında atlanmamış olması; Öndeyiş ve Epilog bölümlerinin her iki farklı tercümede de yerini almış olması; Postmodern ilkelerin farklı ülkelerdeki baskılarında muhafaza edilmediğini göstermesi bakımından değerlidir. Esasen bir Paratekst unsuru olan roman ismi de, orijinal italyanca baskısına sadık kalınarak, her iki tercümede 'Gülün Adı' olarak baskıdan çıkmıştır. Umberto Eco'nun kendisi, gül isminin metaforik bir anlam taşıdığını ve birçok anlama gelebileceği için bu ismi seçtiğini söylemiştir. Postmodern romanlar gizem taşıdığı için Paratekst elbette her şeyi ele vermemekte ancak okura ön bilgi sunmaktadır.

Kapak sayfası temel Paratekst unsurlardan biridir ve her iki kitabın kapağı birbirinden farklıdır. Türkiye baskısının ön kapağında olay yeri 'Melk' Manastırını temsilen bir haç bulunurken kuşbakışı çizilmiş olan kırmızı gül de romanın ismine işaret etmektedir. Makedonca yayınının ön ve arka kapağında bir bütün olarak duran karanlık odadaki iki kitap da 7 günde 7 cinayet işlenmesine sebep olan ve olay yeri Melk Manastırı'nın kalbi sayılan kütüphanede yer alan ve karanlık bir odada saklanan zehirli kitaba gönderme yapılmaktadır. Romanın orijinalinin bir baskısında yer alan ve bir dergiden alınan 'Son Yaprak' alt başlıklı yazı Makedonca baskısında yer almamaktadır. Ancak iki baskı arasındaki esas farklılık Makedonca yayınlarda neredeyse hiç rastlanmayan çevirmenin düşüncesine yer verilen kısımda görülmektedir. Bu romanda Şadan Karadeniz' in kaleminden çıkan ve Türkçeye tercüme edilen birçok Türk romanında çevirmenin sözü, ki kitabın Can Yayınları tarafından yapılan tercümesinde 'Çeviriye Değin' ismini taşıyan kısımdır; Türkiye yayınlarında önemsenen bir durumdur. Türkiye yayınlarında önem verilen bu uygulama dolayısıyla yeni bir Paratekst unsuru daha yaratmıs olur. Aynı konu Makedonca tercümelerde yeterli değeri görmediği için de Paratekst metinler 
bağlamında bir farklılık oluşturmuş hatta Türkiye yayınlarında yapılan bu ekleme Paratekst açısından bir zenginlik ortaya koymuştur. Roman hakkında ön bilgiler verdiği için, çevirmen tarafından yapılan bu ekstra yorum Türkiye yayınlarının doğrudan Paratekst bilgi verme konusunda Kuzey Makedonya'ya kıyasen daha zengin olduğunu da kanıtlayan bir husus olmuştur.

\section{Kaynakça}

Aslan, S., Abdullah, Y. (2001). Modernizme Bir Başkaldırı Projesi Olarak Postmodernizm. Cumhuriyet Üniversitesi Iktisadi ve Idari Bilimler Dergisi, 2(2), 93108

Connor, S. (2001). Post-Modernist Kültür (Çağdaş Olanın Kuramlarına Bir Giriş). (Doğan Şahinler, Çev.). İstanbul: Yapı Kredi.

Çetişli, İ. (2015). Batı Edebiyatında Edebi Akımlar. Ankara: Akçağ.

Doltaş, D. (1999). Postmodernizm Tartışmalar ve Uygulamalar. İstanbul: Telos.

Daddesio, T. C. (1988). The Role of the Paratext in The Name of the Rose. Semiotics: 1988. Minnesota: College of St. Benedict.

Genette, G. (1987). Paratexts: Thresholds of Interpretation. Cambridge: Cambridge University Press.

Koçakoğlu, B. (2011). Postmodernin Geleneğe Bakan Yüzünde Bir Anlatı: Beyaz Kale. Selçuk Üniversitesi Türkiyat Araştırmaları Dergisi, (29), 185-202.

Lukács, G. (1971). Romanda Koşullanma ve Tarihsel Düşünsel Alan. Türk Dili, 234.

McHale, B. (1977). Postmodern Fiction. New York: Methuen Inc. Press.

Menteşe, O. B. (1995). Sanatta Edebiyatta Postmodernizm. Türk Dili, 519.

Menteşe, O. B. (1996). Roman'da Kurumlaşmış Biçimin Yıkılışı ve Yenilikçi 'Avant-Garde' Görüş, Bir Düşün Yolculuğu (Edebiyat-Sanat-Eleştiri Yazıları). Ankara: Bilkamat.

Pannwitz, R. (1917). Die Krisis der europaeischen. Nürnberg: H. Carl.

Şaylan, G. (2002). Postmodernizm. Ankara: İmge.

Toynbee, A. J. (1934). A Study of History. London: Oxford University Press.

Yalçın-Çelik, S. D. (2005). Yeni Tarihselcilik Kuramı ve Türk Edebiyatında Postmodern Tarih Romanları. Ankara: Akçă̆.

Yamaner, G. (2007). Postmodernizm ve Sanat. Ankara: Algı. 
Yaprak, T., Bayrak, Ö. (2017). Bir Mesnevi Parodisi Olarak Benim Adım Kırmızı. Hikmet-Akademik Edebiyat Dergisi [Journal of Academic Literature]. Gelenek ve Postmodernizm Özel Sayısı, (3).

\section{İncelenen Romanlar:}

Eco, U. (2016). Gülün Adı. (Şadan Karadeniz, Çev.). İstanbul: Can.

Еко, У. (2006). Името на розата. (Марија Грација Цветковска, Çеv.). Скопје: Табернакул. / Eko, U. (2006). Imeto na rozata. (Mariya Gratsiya Tsvetkovska, Çev.), Skopye: Tabernakul. 